\title{
Lifting the burden: a coordinated approach to action on Aboriginal tobacco resistance and control in NSW
}

\author{
Jasmine Sarin ${ }^{a, e}$, Jennifer Hunta, Rowena Ivers ${ }^{b, c}$ \\ a Aboriginal Health \& Medical Research Council of New South Wales, Sydney, Australia \\ b Illawarra Aboriginal Medical Service, Wollongong, NSW, Australia \\ c University of Wollongong, NSW, Australia \\ d Centre for Population Health, NSW Ministry of Health, Sydney, Australia \\ e Corresponding author: jsarin@ahmrc.org.au
}

\section{Article history}

Publication date: July 2015

Citation: Sarin J, Hunt J, Ivers R, Smyth C. Lifting the burden: a coordinated approach to action on Aboriginal tobacco resistance and control in NSW. Public Health Res Pract. 2015;25(3):e2531528. doi: http:// dx.doi.org/10.17061/phrp2531528

\section{Key points}

- The Aboriginal Health \& Medical Research Council and the New South Wales Ministry of Health have worked in partnership to develop The ATRAC Framework: A Strategic Framework for Aboriginal Tobacco Resistance and Control in NSW

- The ATRAC Framework identifies relevant evidence, key principles and best-practice approaches for reducing Aboriginal smoking and related harms in NSW

- For the framework to be successful, it requires Aboriginal leadership and the significant involvement of Aboriginal people and Aboriginal community controlled health organisations in all aspects of developing, implementing and evaluating tobacco resistance and control activities targeting Aboriginal people

\section{Abstract}

Smoking prevalence continues to be significantly higher among Aboriginal people than non-Aboriginal people, resulting in a range of serious health consequences and inequities. The Aboriginal Health \& Medical Research Council of New South Wales (AH\&MRC) and the New South Wales (NSW) Ministry of Health (the Ministry) have worked in partnership to develop The ATRAC Framework: A Strategic Framework for Aboriginal Tobacco Resistance and Control in NSW, in collaboration with Aboriginal communities and a range of stakeholders.

The goal of the ATRAC Framework is to reduce smoking prevalence and the harmful impacts of tobacco use among Aboriginal people and communities in NSW. The framework includes reviews of relevant evidence and recommended actions, organised under six areas: leadership, partnerships and coordination; community action, awareness and engagement; workforce development; supportive environments; quitting support; and evidence, evaluation and research.

The framework stresses that, to be successful, Aboriginal tobacco resistance and control programs and activities need to be evidence based, coordinated, integrated and involve Aboriginal people and Aboriginal community controlled health organisations in all aspects, from development through to implementation and evaluation. Consultations and evidence reviews highlight the importance of workforce support and development, including the ongoing need for more workers specialising in Aboriginal tobacco resistance and control, as well as ongoing training for all staff involved in delivering care to Aboriginal people. Other key strategies identified in the framework include improving access to nicotine replacement therapy and other medications to support quitting; supporting, strengthening and building on existing innovative community-based programs; and further developing the evidence base.

The AH\&MRC and the Ministry will continue to work in partnership to drive the use of the ATRAC Framework by all people involved in Aboriginal tobacco resistance and control in NSW for resource allocation, planning, implementation and evaluation of existing and future activities. 


\section{Setting the scene}

The importance of addressing smoking is well recognised in Aboriginal communities, because tobacco is the leading contributor to the gap in life expectancy between Aboriginal and Torres Strait Islander peoples and the general population. ${ }^{1}$ Smoking contributes most to the higher mortality rates seen for many cancers among Aboriginal people, and is a risk factor for many other diseases, including cardiovascular disease and chronic lung disease. ${ }^{2}$ In New South Wales (NSW), Aboriginal people are more than twice as likely to report current smoking as non-Aboriginal people. ${ }^{3}$ Although smoking prevalence for Aboriginal people has begun to decline, the benefits observed from reduced smoking rates in other population groups over recent decades are yet to be experienced by Aboriginal people. ${ }^{4}$

The role of the Aboriginal community controlled health sector is essential to building healthier Aboriginal communities. Aboriginal community controlled health services (ACCHSs) focus on prevention and early intervention in their delivery of comprehensive Aboriginal primary health care, and have been instrumental in improving access to care and individual health outcomes for Aboriginal people. ${ }^{5}$ The Aboriginal Health \& Medical Research Council of NSW (AH\&MRC) is the peak representative body and voice of Aboriginal communities about health in NSW, supporting and representing 50 ACCHSs throughout the state.

The ACCHS sector, including the AH\&MRC, has been active in addressing Aboriginal tobacco issues for many years. The AH\&MRC currently delivers the Aboriginal Tobacco Resistance and Control (A-TRAC) Program, introduced in 2009 and supported by funding from the NSW Ministry of Health (the Ministry). The A-TRAC Program has a focus on supporting ACCHSs in the development and delivery of locally tailored and culturally appropriate programs to address smoking in Aboriginal communities.

\section{The need for a framework}

An emerging evidence base supports an increased and sustained focus on activities to reduce smoking prevalence among Aboriginal people and the resulting negative impacts on individuals and communities. ${ }^{6}$ This includes high-quality evidence about the effectiveness of interventions to reduce smoking prevalence in the general population, such as telephone advice, price increases and taxation, and media campaigns. ${ }^{7}$ Existing and emerging evidence supports Aboriginal-specific strategies such as training for Aboriginal health workers and other health professionals about smoking cessation advice, and multicomponent tobacco resistance and control programs. ${ }^{8,9}$ There is a great need for intensive, longer-term programs and more high-quality evidence in this area. ${ }^{10}$
In recent years, a marked increase in investment and levels of activity to address smoking among Aboriginal people by Aboriginal communities, ACCHSs, government and nongovernment agencies has been observed. The NSW Government has set targets to reduce smoking rates by $4 \%$ for all Aboriginal people by 2015 , and by $2 \%$ per year for pregnant Aboriginal women. ${ }^{11}$ To yield maximum benefits and value for money, efforts to address Aboriginal smoking need to be evidence based, coordinated and integrated.

These factors have been the drivers for the AH\&MRC and the Ministry to work in partnership, and in collaboration with Aboriginal communities and a range of stakeholders, to develop The ATRAC Framework: A Strategic Framework for Aboriginal Tobacco Resistance and Control in NSW. ${ }^{12}$

The ATRAC Framework identifies relevant evidence, key principles and best-practice approaches for reducing Aboriginal smoking and harms relating to tobacco use in NSW, and aims to guide and inform the efforts of all involved in Aboriginal tobacco resistance and control efforts in NSW. An overview is shown in Figure 1.

\section{The development process}

The ATRAC Framework was developed by the AH\&MRC and the Ministry under the auspice of the NSW Aboriginal Health Partnership. ${ }^{13}$ A subcommittee of the partnership, including key stakeholders such as ACCHSs, government agencies and nongovernment organisations involved in tobacco control, and research bodies, provided oversight and guidance for the framework development.

The consultation process exemplified and highlighted the importance of a 'bottom-up' approach, creating buyin from those who would be most likely to benefit from, use or be influenced by the framework. Staff working in ACCHSs, Local Health Districts and other stakeholder organisations from rural and urban NSW participated in a range of consultation processes. These included dedicated workshops at the 2013 ATRAC Symposium for ACCHS staff working in tobacco control, and at the Close the Gap Forum hosted by the Ministry in late 2013.

Strong themes emerged from consultations about the importance of Aboriginal leadership and the significant involvement of Aboriginal people and their community controlled organisations in all aspects of developing and implementing tobacco resistance and control activities. Key messages such as taking a long-term and committed approach, and the benefits of integrating tobacco resistance and control activities into other health programs were also stressed during consultations, and incorporated into the framework.

Although there were some challenges, the partnership approach, with the AH\&MRC and the Ministry leading the framework development process, significantly strengthened the working relationship and collaboration between the two organisations. In addition, implementation is likely to be assisted by the ongoing 
Figure 1. ATRAC Framework overview

\section{Goal}

Reduce smoking prevalence and the harmful impacts of tobacco use among Aboriginal people and communities

\begin{tabular}{|c|c|c|c|c|c|c|}
\hline \multicolumn{7}{|c|}{ Objectives } \\
\hline \multicolumn{2}{|c|}{$\begin{array}{l}\text { Increase the number of } \\
\text { Aboriginal people who } \\
\text { quit smoking }\end{array}$} & $\begin{array}{l}\text { Increase the number } \\
\text { of smoke-free homes, } \\
\text { workplaces and public places }\end{array}$ & \multicolumn{2}{|c|}{$\begin{array}{l}\text { Shift Aboriginal community } \\
\text { attitudes away from } \\
\text { smoking being a norm }\end{array}$} & \multicolumn{2}{|c|}{$\begin{array}{l}\text { Prevent uptake of smoking } \\
\text { by Aboriginal people, } \\
\text { particularly young people } \\
\text { and children }\end{array}$} \\
\hline \multicolumn{7}{|c|}{ Areas for action } \\
\hline $\begin{array}{l}\text { Leadership, } \\
\text { partnerships and } \\
\text { coordination }\end{array}$ & $\begin{array}{l}\text { Community } \\
\text { action, awareness } \\
\text { and engagement }\end{array}$ & $\begin{array}{l}\text { Workforce } \\
\text { development }\end{array}$ & $\begin{array}{l}\text { Supportive } \\
\text { environments }\end{array}$ & \multicolumn{2}{|c|}{ Quitting support } & $\begin{array}{l}\text { Evidence, } \\
\text { evaluation and } \\
\text { research }\end{array}$ \\
\hline \multicolumn{7}{|c|}{ Examples of recommended actions $s^{a}$} \\
\hline $\begin{array}{l}\text { - Strengthen } \\
\text { Aboriginal } \\
\text { tobacco control } \\
\text { networks and } \\
\text { networking } \\
\text { activities } \\
\text { - Promote } \\
\text { and support } \\
\text { partnerships and } \\
\text { collaboration } \\
\text { between } \\
\text { different } \\
\text { sectors and } \\
\text { organisations }\end{array}$ & $\begin{array}{l}\text { Develop, } \\
\text { implement } \\
\text { and evaluate } \\
\text { localised } \\
\text { approaches, } \\
\text { developed by } \\
\text { communities, } \\
\text { to promoting } \\
\text { quitting and } \\
\text { reducing } \\
\text { exposure to } \\
\text { second-hand } \\
\text { smoke }\end{array}$ & $\begin{array}{l}\text { - Train, employ } \\
\text { and support } \\
\text { specialised } \\
\text { positions for } \\
\text { Aboriginal } \\
\text { workers to } \\
\text { focus on } \\
\text { tobacco control } \\
\text { and smoking } \\
\text { cessation in } \\
\text { ACCHSs and } \\
\text { other healthcare } \\
\text { settings }\end{array}$ & $\begin{array}{l}\text { Promote smoke- } \\
\text { free role models } \\
\text { and smoke- } \\
\text { free events } \\
\text { for Aboriginal } \\
\text { people through } \\
\text { ACCHSs and } \\
\text { other Aboriginal } \\
\text { community } \\
\text { organisations, } \\
\text { Local Health } \\
\text { Districts, } \\
\text { Primary Health } \\
\text { Networks and } \\
\text { in the broader } \\
\text { Aboriginal } \\
\text { community }\end{array}$ & \multicolumn{2}{|c|}{$\begin{array}{l}\text { - Develop and } \\
\text { implement } \\
\text { policies and } \\
\text { systems in } \\
\text { ACCHSs and } \\
\text { mainstream } \\
\text { health services } \\
\text { that support the } \\
\text { provision of brief } \\
\text { interventions } \\
\text { for smoking } \\
\text { cessation for } \\
\text { Aboriginal } \\
\text { people who } \\
\text { smoke }\end{array}$} & $\begin{array}{l}\text { - Strengthen } \\
\text { and enhance } \\
\text { Aboriginal } \\
\text { community } \\
\text { and ACCHS } \\
\text { capacity in } \\
\text { research project } \\
\text { evaluation } \\
\text { - Develop } \\
\text { transferable } \\
\text { models for } \\
\text { evaluating } \\
\text { community } \\
\text { Aboriginal } \\
\text { tobacco } \\
\text { resistance } \\
\text { and control } \\
\text { initiatives }\end{array}$ \\
\hline
\end{tabular}

ACCHSs = Aboriginal community controlled health services

a The full list of recommended actions can be accessed at ATRAC: www.ahmrc.org.au/index.php?option=com_content\&view=article\&id=20\&Itemid=21

engagement of stakeholders through both organisations' networks, as well as the collaborative and participatory processes used for the development of the framework.

\section{The ATRAC Framework content}

The ATRAC Framework identifies a range of strategic approaches for taking action on smoking in Aboriginal communities, and highlights the importance of Aboriginal people, communities and community organisations being involved in the design, delivery and evaluation of all programs and activities targeting Aboriginal people, to maximise their effectiveness. The need for specialist Aboriginal tobacco resistance and control workers, and related support for networking and coordination across the state is emphasised. Recommended workforce development initiatives include ongoing training in tobacco control for all health professionals who work with Aboriginal people in both Aboriginalspecific and mainstream settings. Access to subsidised pharmacotherapies such as nicotine replacement therapy (NRT), including over-the-counter NRT, was supported. In addition, the involvement of Aboriginal people and organisations in the development of Aboriginal-specific media campaigns, as well as broader tobacco programs, including the development of media advertising campaigns and new anti-tobacco legislation, are identified as key strategies.

The framework particularly highlights the value of focusing on increasing the capacity of Aboriginal communities, particularly strengthening the efforts of the ACCHS sector, to undertake tobacco resistance and control activities, building on existing efforts.

Also prominent in the framework is the critical importance of efforts to address smoking being coordinated and integrated - with each other, with efforts to address smoking in the general population, and within other Aboriginal health programs and activities. The roles of key organisations in Aboriginal tobacco resistance and control in NSW are outlined in the framework to assist with 
coordination and integration through enabling a better mutual understanding of roles and responsibilities.

The ATRAC Framework identifies six 'areas for action', and describes a rationale and a series of specific recommended actions for each. Collectively, these recommendations provide a comprehensive blueprint of agreed future actions to address smoking among Aboriginal people in NSW.

\section{From framework to action}

Increasing engagement and activity among NSW ACCHSs in tobacco resistance and control in recent years is demonstrated by the growth in participation in the annual ATRAC Symposium and the Aboriginal Tobacco Resistance Network supported by the AH\&MRC, as well as by more requests from ACCHSs for resources and support. The AH\&MRC has observed a marked growth in the number of NSW ACCHSs developing and delivering innovative, culturally informed, local preventive health programs and resources.

The ATRAC Framework provides a mechanism to build on and support these Aboriginal community-led efforts, coordination and integration, by being a practical tool to guide and inform all involved in Aboriginal tobacco resistance and control in NSW. It will be used by different parties in different ways, including to inform decision making about resource allocation, planning, implementation and evaluation of existing and future activities at local, regional and state levels.

The AH\&MRC and the Ministry will continue to work in partnership to support the use of the ATRAC Framework, and to drive ongoing, evidence based, coordinated action to address smoking in NSW Aboriginal communities, towards the goal of achieving lasting improvements in the health and wellbeing of NSW Aboriginal people.

\section{Competing interests}

None declared

\section{Author contributions}

Each of the authors made a substantial contribution to the concept of the paper. Each of the authors made a substantial contribution to the drafting of the work or revising it critically and providing final approval.

\section{References}

1. Vos T, Barker B, Begg S, Stanley L, Lopez AD. Burden of disease and injury in Aboriginal and Torres Strait Islander Peoples: the Indigenous health gap. Int J Epidemiol. 2009;38(2):470-7.
2. Cunningham J, Rumbold AR, Zhang X, Condon JR. Incidence, aetiology, and outcomes of cancer in Indigenous peoples in Australia. Lancet Oncol. 2008;9(6):585-95.

3. Centre for Epidemiology and Evidence. The health of Aboriginal people of NSW: Report of the Chief Health Officer. Sydney: NSW Ministry of Health; 2012 [cited 2015 May 20]. Available from: www.health.nsw.gov.au/ epidemiology/Pages/aboriginal-cho-report-2012.aspx

4. Thomas D. Smoking prevalence trends in Indigenous Australians, 1994-2004: a typical rather than an exceptional epidemic. Int J Equity Health. 2009;8(1):37.

5. Panaretto KS, Wenitong M, Button S, Ring IT. Aboriginal community controlled health services: leading the way in primary care. Med J Aust. 2014;200(11):649-52.

6. Ivers R. Anti-tobacco programs for Aboriginal and Torres Strait Islander people. Canberra: Australian Institute of Health and Welfare and Melbourne: Australian Institute of Family Studies; 2011 [cited 2015 May 20]. Available from: www.aihw.gov.au/uploadedFiles/ClosingTheGap/Content/ Publications/2011/ctgc-rs04.pdf

7. Wakefield MA, Durkin S, Spittal MJ, Siahpush M, Scollo M, Simpson JA, et al. Impact of tobacco control policies and mass media campaigns on monthly adult smoking prevalence. Am J Public Health. 2008;98(8):1443-50.

8. Ivers RG, Castro A, Parfitt D, Bailie RS, D’Abbs PH, Richmond RL. Evaluation of a multi-component community tobacco intervention in three remote Australian Aboriginal communities. Aust N Z J Public Health. 2006;30(2):132-6.

9. Power J, Grealy C, Rintoul D. Tobacco interventions for Indigenous Australians: a review of current evidence. Health Promot J Austr. 2009;20(3):186-94.

10. Carson K, Newchurch J, Peters M, Esterman A, Singh K. Smoking cessation and tobacco abuse prevention in Indigenous populations. Evidence Base. 2014(3):1-50.

11. Department of Premier and Cabinet. NSW 2021: a plan to make NSW number one. Sydney: New South Wales Government; 2011 [cited 2015 May 20]. Available from: www.nsw.gov.au/2021

12. NSW Ministry of Health and Aboriginal Health \& Medical Research Council of NSW. The ATRAC framework: a strategic framework for Aboriginal tobacco resistance and control in NSW. Sydney: NSW Ministry of Health;2015 [cited 2015 May 20]. Available from: www.ahmrc.org.au/index. php?option=com_content\&view $=$ article\&id=20\&ltemid $=21$

13. Aboriginal Health \& Medical Research Council of NSW and NSW Health. NSW Aboriginal health partnership agreement 2008-2013. Sydney: NSW Department of Health; 2008 [cited 2015 May 15]. Available from: www.health.nsw.gov.au/aboriginal/Documents/pubpartnership.pdf

\section{Copyright: C()(9)}

(c) 2015 Sarin et al. This article is licensed under the Creative Commons Attribution-NonCommercial-ShareAlike 4.0 International Licence, which allows others to redistribute, adapt and share this work non-commercially provided they attribute the work and any adapted version of it is distributed under the same Creative Commons licence terms. See: www.creativecommons.org/licenses/by-nc-sa/4.0/ 